\title{
Kate and Kathleen: Irishwomen Abroad and the Quest(ion) of Identity
}

\section{Angela Ryan}

\section{(2) OpenEdition}

1 Journals

\section{Electronic version}

URL: https://journals.openedition.org/etudesirlandaises/8472

DOI: 10.4000/etudesirlandaises.8472

ISSN: 2259-8863

\section{Publisher}

Presses universitaires de Caen

\section{Printed version}

Date of publication: 31 December 2019

Number of pages: 113-125

ISBN: 978-2-84133-964-8

ISSN: 0183-973X

\section{Electronic reference}

Angela Ryan, "Kate and Kathleen: Irishwomen Abroad and the Quest(ion) of Identity", Études irlandaises [Online], 44-2 | 2019, Online since 06 May 2020, connection on 14 November 2022. URL: http:// journals.openedition.org/etudesirlandaises/8472 ; DOI: https://doi.org/10.4000/etudesirlandaises. 8472

\section{(c) (1) (ㅇ)}

Creative Commons - Attribution-NonCommercial-ShareAlike 4.0 International - CC BY-NC-SA 4.0 https://creativecommons.org/licenses/by-nc-sa/4.0/ 


\title{
Kate and Kathleen: Irishwomen Abroad and the Quest(ion) of Identity
}

\begin{abstract}
This essay compares the writing of Kate O'Brien, celebrated Irish novelist who travelled to Spain and worked mainly in Britain, and of her less well-known cousin by marriage Kathleen Fitzpatrick Bernard, who travelled to France and settled in Paris. Both writers explored modernist styles, including stream of consciousness, and represented themes of exile, elsewhere, and the quest for identity, especially for young Irishwomen going abroad to escape the then narrow range of "respectable" life-choices.
\end{abstract}

Keywords: Kate O’Brien, Kathleen Fitzpatrick Bernard, 1930s-1950s Ireland, exile-writing, female identity-quest.

Résumé: Cet article propose une lecture croisée de l'œuvre de Kate O’Brien, romancière irlandaise reconnue qui s'installa en Angleterre après avoir parcouru l'Espagne, et de Kathleen Fitzpatrick Bernard, sa cousine par alliance, moins connue, qui, elle, s'installa à Paris après avoir voyagé dans la France entière. Résolument modernistes, leurs œuvres explorent différents styles, dont le flux de la conscience, et s'intéressent aux thèmes de l'exil, de l'ailleurs et de la quête d'identité - en particulier celle de jeunes Irlandaises choisissant de quitter l'Irlande et les normes restrictives qui régissaient à l'époque la «respectabilité».

Mots clés: Kate O'Brien, Kathleen Fitzpatrick Bernard, Irlande des années 1930-1950, écriture de l'exil, quête de l'identité féminine.

The theme of elsewhere, as a quest for identity, especially for the female heroine or $I$-persona, is strong in the writings both of Kate O'Brien and her cousin by marriage Kathleen Fitzpatrick Bernard. O'Brien was celebrated and very successful throughout her career as a journalist, travel writer, novelist and playwright, winning the James Tate Black Prize and the Hawthornden Prize for Without My Cloak, her first novel. Two of her novels were however banned in Ireland, one, The Land of Spices ${ }^{1}$, because it contained one reference to non-conventional sexuality (male-male sexuality). Fitzpatrick Bernard wrote throughout her life, but published little formally; her work was known to a group of friends, fellow writers and academics with whom she shared intellectual interests ${ }^{2}$ and amongst whom her fiction/autofiction and

1. Kate O'Brien, The Land of Spices [1941], London, Virago (Virago Modern Classics), 2006.

2. My grateful thanks are due to Kathleen Fitzpatrick Bernard's spouse, Professor Philippe Jacques Bernard, author of De l'utopie moderne et de ses perversions, Paris, Presses universitaires de France, 1997; Histoire du développement économique, XVII ${ }^{e}-X X^{e}$ siècle, Paris, Ellipses, 1989, for his most kindly-given access to her writings and correspondence, and ongoing support of my research into the archive, a fascinating picture of the lived experience of literary Irishwomen in the period, 
poems were circulated. She also occasionally wrote for The Irish Times as "Our Paris Correspondent".

As to style, close study of their writings, the famous writer and the little-known, shows a number of similarities and comparabilities of style, especially the use of modernist stream of consciousness. This paper looks at examples from Kathleen Fitzpatrick Bernard's fiction / autofiction Pattern ${ }^{3}$, and her collection of poetry Kitchen Wings ${ }^{4}$, and Kate O'Brien's novels Mary Lavelle ${ }^{5}$ and That Lady ${ }^{6}$.

Kate (born Kathleen) O'Brien was born on 3 December 1897 and died in Canterbury aged seventy-six on 13 August 1974. Her cousin by marriage Kathleen Fitzpatrick Bernard, often known as Kitty, was born on 30 November 1917 and died in Paris 14 July 2009 aged ninety-two. Both writers went to school at Laurel Hill, one of the many girls' schools set up in Ireland by French or French-speaking nuns in the $19^{\text {th }}$ century, and both later studied French at University College Dublin (the alma mater of the present writer, who also attended a convent boarding school, albeit one more in the French Enlightenment tradition of Juilly and the abbé Bautain ${ }^{7}$ ). Both writers went abroad to European Catholic countries, respectively Spain and France, and engaged profoundly in each case with this new culture: O'Brien set two of her novels there, and a travel-writing work, while going to live in England for much of her later life, where she could express her, at the time, counter-cultural sexuality. Fitzpatrick Bernard went to Paris initially for a stay abroad related to her academic study, married a French intellectual and academic, and settled for life in Paris, retaining contact with Ireland and the Irish, and making heroic efforts to build and maintain a literary career in a period where women, especially mothers of large families, faced even more barriers to creative fulfilment than those which still remain today in so many cases, despite much progress made, and not only in Ireland.

Kathleen Fitzpatrick Bernard's archive includes an article in The Irish Times of 2 July 1970, by Kate O’Brien, on Paris, describing a “magical drive” taken with Kathleen and her husband Philippe, all around the Paris both Kathleens loved. O'Brien refers to Fitzpatrick Bernard thus: "Kitty Bernard was Irish until, about 18 years ago, she married Philippe Bernard"; at the time, the question of the name and nationality of married women was not yet problematized as it is today.

and the subject of the wider research of which this article is a part. Thanks are further due to her children Anne Bernard Kearney, Catriona Bernard, Frédéric Bernard and Emmanuel Bernard for memories shared in interview.

3. Kathleen Fitzpatrick Bernard, Pattern, Paris, undated (informal dissemination).

4. Kathleen Fitzpatrick Bernard, Kitchen Wings, Paris, undated (informal dissemination). A number of the poems are indicated as "already published" or read on Dublin radio.

5. Kate O’Brien, Mary Lavelle, London, Heinemann, 1936.

6. Kate O'Brien, That Lady, London, Heinemann, 1946.

7. Saint Louis Convent, run by the Sisters of Saint Louis, whose motherhouse school at Juilly was originally founded by Blanche of Castile, mother of Louis IX of France or Saint Louis, and which maintained for many years a tradition of education by debate rather than the more conventional learning by rote. See Meánscoil Lughaidh Muineachán 1859-2013: A Trip Down Memory Lane, Monahan, Clann Lughaidh, 2013. 
Allowing for one having lived sixteen years longer than the other, their timelines overlap in much the same period in Irish social history, and both writers, despite the difference in level of fame, have in common, amongst other things, the thematic presence in their work of exile as escape and self-discovery, especially for women.

The Ireland of their lives as young women in the 1920s-1930s, was far from the Ireland of today ${ }^{8}$; today's Ireland has made huge advances in its response to diversity and freedom of opinion, whilst still falling behind some other modern states in liberal values. What is interesting about Ireland, and about the Irelands of O'Brien and Fitzpatrick Bernard's writing, is the co-existence of the most open, liberal and rational mindsets in so many people, with a no less prevalent culture of appearance, endorsing in public discourse more conventional and traditional views of human existence.

This complexity has led in the past, for example, to birth control being illegal, pre-1980, but available in practice, under other guises, to women who could access the "right" doctor, etc., usually because in situations of higher levels of education and privilege, whilst women living in less affluent, perhaps in less bourgeois milieux, financially and in terms of attitudes and expectations, would have found such access more difficult, practically and psychologically. There is a mindset paradox between public discourse, and attitudes to persons: tolerating the existence of different behaviours in persons can seem, and often is, very ready, in Ireland. However, actually validating these behaviours in public, making them a right, and embracing collective responsibility for them, is still problematic.

The 2018 referendum on decriminalising voluntary pregnancy termination marks a major step in progress beyond this double standard. The speech by Micheál Martin $^{9}$ from the traditionally conservative Fianna Fáil party, in favour of decriminalisation, was a new departure (and arguably a courageous act). The well-known fact that women went abroad, especially to Britain, to avail of legal pregnancy termination, was admitted into the current debate instead of the pretence that it did not occur, as was the case in earlier times. Another strand in the tapestry seems to be the presence at such times in Irish affairs of a certain "Memory Ireland", a nostalgia on the part of various groups, wishing to preserve a largely imaginary idealised traditional Ireland in the face of universal change, or even a return to what the singer Sinéad O'Connor has called "theocracy" ${ }^{10}$ Sometimes the groups are made up of celibate men in the fundamentalist areas of a powerful and wealthy institution. Sometimes there is a foreign presence of far-right people desiring to preserve a traditional Ireland as a kind of moral Edenic idealised point of origin, in which women obey.

8. See Dublin 1904-1924. Réveil culturel, révolte sociale, révolution politique: un patriotisme déchiré, Patrick Rafroidi, Pierre Joannon, Maurice Goldring (eds.), Paris, Autrement, 1991; Cahiers du Centre d'études irlandaises, no. 11, 1987, Irish Women Today, Angela Ryan (ed.).

9. Pat Leahy, "Micheál Martin's Abortion Stance a Response to Strong Mood for Change: The Promise of Change, Renewal, Reform is a Very Powerful Political Trope", The Irish Times, 20 January 2018.

10. “To Sinéad O’Connor, The Pope's Apology for Sex Abuse in Ireland Seems Hollow”, The Washington Post, 28 March 2010. 
Former President of Ireland Mary Robinson served in the Irish Seanad (Senate) from 1969, first as an Independent and later as a member of the Labour Party, and campaigned for the legalisation of contraception, for the right of women to serve on juries, the decriminalisation of homosexuality, and other liberal causes. By the time she was elected as Uachtarán (President) in 1997, most of these causes had advanced significantly, despite the opposition she faced, even from colleagues who feared the political expediency of these causes - again, the unwillingness to affirm liberal values and rights in public overriding an often high level of tolerance in private. Putting it in terms of structure and counter-structure, the counterstructures can be very enabling, often more especially for the educated bourgeois, compensating (but insufficiently) for the rigid and oppressive structures ${ }^{11}$. The attitudes restricting women's bodily freedom and causing other restrictions have by no means disappeared entirely even today, so that the period in which O'Brien and Fitzpatrick Bernard reached young adult womanhood was one in which going abroad could be seen as escape to freedom, at many levels. The theme of exile, and the act of writing go together, in this life-experience. The loss of home was also a gain of personal freedom; the act of writing was giving voice to the silenced experience of women in a society where a male-dominated establishment told women what they might and might not do with their bodies, what relationships, what jobs were acceptable ${ }^{12}$.

Young women travelling abroad in the time of O'Brien or Fitzpatrick Bernard had many concrete restrictions to escape; it is equally present in their writing, in its life-writing aspects, that the prison bars are also mental: internalised expectations or authority-figures; an acceptance of the penalties for failure to comply; aspiration towards the ideals which the public morality would seek to preserve, albeit through severe and fundamentalist penalisation of those who disagree (or simply find the aspirations not always possible to reach).

Whether abroad would in fact always offer a more favourable environment for self-realisation is more problematic, as will be seen in both writers' works. This problematic is shared with many Irish writers of the modern period. In the case of O'Brien and Fitzpatrick Bernard, there is added a content related to women's freedom, that of going abroad to escape the restrictions on young women's lives in Ireland at the time. The escape is not simple and not unproblematic; as George Sand wrote at an earlier period, the traveller brings with them abroad the issues at home ${ }^{13}$. The $I$-persona and You-persona of Fitzpatrick Bernard's Pattern (a poeticprose text in modernist style, involving sequences of lived experience and memory, related to a young woman's passage to adult life) do not express overt negativity

11. For an outline of the theory of structure and counter-structure, see Angela Ryan, "Memetics, Metatranslation and Cultural Memory: The Literary Imaginaires of Irish Identity", in The Languages of Ireland, Michael Cronin, Cormac Ó Cuilleanáin (eds.), Dublin, Four Courts Press, 2003, p. 196-216.

12. The marriage bar in the Civil Service was repealed in 1973.

13. George Sand, Un hiver à Majorque, Angela Ryan (ed), in Euvres complètes, 1841-1842, Béatrice Didier (ed.), Paris, H. Champion, 2013, p. 66. 
about the Irish bourgeois milieu, in which they were brought up and to which they are expected to conform; complexities of motivation mix love for family, and desire for independence. Lorna Reynolds and Bridget Hourican's analysis in the Dictionary of Irish Biography speaks of Kate O’Brien but it can be applied to both writers in the voices of their heroines:

[...] the archetypal plot involves a young, beautiful, intellectual, moral girl seeking independence from her bourgeois family, undergoing some kind of a crisis, frequently sexual, finding only transient happiness, and left, at the end, alone but with self-knowledge ${ }^{14}$.

In addition to a significant level of female revolt and quest for freedom - albeit expressed with ladylike restrained language, to our eyes today - both writers experiment with modernist styles in their writing, particularly various forms of stream of consciousness. They embody a mode of writing which is by no means universal in Irish writing, that of the Catholic intellectual novelist ${ }^{15}$. Both writers, well-educated, literary, highly educated, would have been especially open to such influences as the French Catholic intellectual novel, those of Francois Mauriac for example.

A more circumstantial literary influence, related to moving out of Ireland, would have been the availability of books which were banned in Ireland (as some of O'Brien's were later to be, indeed). Banned books in the decades following Irish independence included such writers as Liam O'Flaherty (The House of Gold, 1929), Eric Cross (The Tailor and Ansty, 1942), Maura Laverty (Alone We Embark, 1943; Lift Up Your Gates, 1946), Frank O'Connor (The Midnight Court, 1946). Some banned authors later became required reading on state examination programmes, for example in anthologies edited by Professor Augustine Martin ${ }^{16}$. Ryle Dwyer stated in the Irish Examiner ${ }^{17}$ that Edna O'Brien's The Lonely Girl was banned in 1962 following a personal approach by the Archbishop of Dublin, John McQuaid, to the then Minister of Justice (later Taoiseach) Charles Haughey.

A comparison between Fitzpatrick Bernard's fiction Pattern, and O’Brien's novel Mary Lavelle highlights the representation of young Irish women moving abroad, respectively to France and Spain, in a kind of rite of passage period, one which is going to be enormous in its impact on the future, in ways they imagine, and in ways they certainly do not:

14. Lorna Reynolds, Bridget Hourican, "Kate O’Brien” in Dictionary of Irish Biography, James Mcguire, James Quinn (eds.), Cambridge, Royal Irish Academy - Cambridge University Press, 2009.

15. See discussion of this tradition in Angela Ryan, “'A Franco-Irish Solution?' Francois Mauriac, Kate O'Brien and the Catholic Intellectual Novel”, in France and Ireland: Anatomy of a Relationship, Eamon Maher, Grace Neville (eds.), Frankfurt, P. Lang, 2004, p. 97-109. Professor Lorna Reynolds, in conversation with the present author, expressed the view that O'Brien had certainly read Mauriac.

16. Introducing English: An Anthology of Prose and Poems, Augustine Martin (ed.), Dublin, Gill \& Macmillan, 1970.

17. Ryle Dwyer, “There Was Some Truth in Paisley's Tirades Against Our Priestly Republic”, Irish Examiner, 14 August 2010. 
Thank goodness term would soon be ending and you could leave their house. [...] Sheila had taken your leaving badly. The end of friendship? Everything seemed to be crumbling. Soon time to go to France. At least three months the professor advised. [...] Ten children and a husband who drank. - Yes, his house is lovely and Auntie May is a great housekeeper. - A good wife. Always a bit distant. Why didn't she come today?" 18

The modernist stream-of-consciousness writing style foregrounds the upheaval of a period of life choices, in early adulthood: a wish for change, for otherness, for elsewhere. Going abroad is desired, but not without anxiety and a sense of possible loss ("end of friendship?"); these thoughts are followed by intense evocation of the fate of women at home. For married women at the time, unless fortunate, the reality is of frequent pregnancies, subjection to marital control, at a time when the concept of marital rape does not yet exist, nor divorce, and contraception is criminalised, as is pregnancy termination (until 2018). The corollary to unchosen pregnancies might be the relative absence of sexual fulfilment in marriage; for example where male homosexuality, still criminalised and socially stigmatised, used marriage as a cover, or to have an heir for socio-economic reasons.

None of these socio-anthropological givens is referenced quite so explicitly, in the mind of the I-persona of Pattern (any more than for the eponymous heroine of Mary Lavelle), but awareness of them underpins the intensity of the narrative. As the writing continues, the narrative you alternates with a narrative $I$, in Fitzpatrick Bernard's modernist style, to evoke the fate of women as forced to breed or remain celibate:

A terrible thought ten children. If I ever marry Dave had said 'twill be to have children. So love was all a hoax. The woman an incubator. A chattel. [...] ${ }^{19}$

Rosita Sweetman's books On Our Backs ${ }^{20}$ and On Our Knees ${ }^{21}$ shocked as late as the 1970s by their frank analysis of life for Irish women, still hugely confined and restricted by the subservience of most politicians, and many media, to Catholic Church control and influence. How much more these would have weighed on young Irishwomen of the generation of O'Brien and Fitzpatrick Bernard may be imagined. Ryle Dwyer's article ${ }^{22}$ also refers to the Church hierarchy having objected in 1950 to the proposed Mother and Child Scheme introduced by the then Minister of Health in an attempt to improve the infant mortality rate in Ireland, at the time one of the highest in Europe. Dwyer relates how in a 2010 televised discussion Bishop Willie Walsh of Killaloe admitted the wrongs of the past and said he was much happier with "the broken Church that's in Ireland today". The I-persona of Pattern might well, as a young woman in Ireland, have feared the non-chosen pregnancies which marriage would be likely to entail.

18. Kathleen Fitzpatrick Bernard, "VI After This our Exile", in Pattern, p. 91-93.

19. Ibid., p. 93.

20. Rosita Sweetman, On Our Backs: Sexual Attitudes in a Changing Ireland, London, Pan Books, 1979.

21. Rosita Sweetman, On Our Knees, London, Pan Books, 1972.

22. Ryle Dwyer, “There Was Some Truth in Paisley's Tirades...”. 
The narrative point of view dominant in Mary Lavelle (1936) is third person indirect free style, moving from the extradiegetic mode - analyzing the situation of young women like Mary from respectable families, with a good education, much better affordances than women from less advantaged social sub-groups, hoping for freedom but nonetheless offered a very limited range of life choices - as here:

But she had no idea that [her profession of governess] was obsolete, and had she thought so would not have greatly cared, for her choice of it as an expedient, however enforcedseeming, reveals her as an individualist, hand-to-mouth and inefficient, but capable of dream and unfit to march with earnestness in the column of female bread-winners, or indeed in any column at all ${ }^{23}$.

Then at times to sequences of more personal language, still expressed in the third person, but with an increased intensity, a greater focus on the internal point of view - the repeated "she becomes [...] because" echoing the heroine's determination to be independent, but also the related anxiety, conveying her emotional state, her essential jeopardy, comparable to that of the heroine of Pattern:

She becomes a miss because not her wits but her institutional antennae tell her that it is an occupation which will let her personality be; she becomes one because she does not want to be anything but herself for long, because she is in love with a young man in Ireland maybe - all the English governesses in Spain are Irish - or is in love with love, or with her home or her religion ${ }^{24}$.

The play with tense and mode in these passages, typical of modernism, focuses on the heroine's predicament, in a quasi-cinematic technique, moving, as it were, from narrative travelling-shot, to a close-up, then to a long-distance representation of the situation as quasi-universal, common to other young women in her time and place. Mary is faced with the prospect of an acceptable marriage back home in Ireland, which she does not really desire. Her feelings about it are rather more assent than consent, that is, agreeing to something when one does not have freedom to choose an alternative (as distinct from a choice which is freely made, where alternatives were equally possible, where survival without making that particular choice was unproblematic).

In the novel, Mary falls in love with the son of the family in which she is staying as a "Miss", an English-language governess. He is already married and any possible relationship will be at best very difficult (disruptive to family relations; legally complicated; they would be unable to live in Ireland or Spain). Mary has genuine ethical concerns with the whole idea. At the same time their feelings are represented as extremely passionate, and also emotionally intelligent: they are a well-suited couple with compatible tastes and values. In these highly restricted societies, persons with well-developed moral centres can become constructed as

23. Kate O’Brien, Mary Lavelle, p. xi.

24. Ibid. 
rebels. They are threatening the socio-economic structures of society. Modernist disruption of earlier classical prose styles can be seen as mirroring the disruption in the period of social norms, which wars and economic crisis had revealed to be no longer any guarantee of stability or security. Thus O'Brien's polite civilized young Irishwoman abroad is a radical thinker, trying for her freedom and happiness, in a new milieu where society's restrictions are less visibly overwhelming, and where she can, as it were, free herself from the expectations of home.

Ultimately, however, the heroines of O'Brien and Fitzpatrick Bernard cannot, as women, get free of the sense of obligation to the greater group. The radicalism of their process lies in each having severed obligation to the greater group on the one hand, and on the other, obligation to any clear greater good. The pull between self and society must be endured, but is no longer represented as fair, or just.

This is highly significant. In an interview with Professor Hélène Cixous some years ago ${ }^{25}$, she voiced the opinion that the medium of expression was always important for women's expression. She did not see the mass media, for example, as being aretaic (value-based) for women, and they could not be so until capitalized by women (if then). Safer modes of communication, in her opinion, were situations of a person or voice speaking to a group, each member of which might then communicate creative expression and ideas, in their turn, to another group, and so on ${ }^{26}$. Creative writing would thus be a privileged location of truth. For example, as I suggested elsewhere ${ }^{27}$, Irish women's short stories of the 1970s period were influential in bringing into the public imaginaire, in a relatively intimate, less threatening way to what was not yet called the echo-chamber, the lived experience of couples without access to contraception, couples crossing the religious divide, people trying to cope with relationship breakdown, etc. At the time, public debate was so polarized as to be quasi impossible - the history of the allowability of discussion even taking place, on e.g. The Late Late Show, is an illustration. Short stories however allowed the imaginative introjection of these very human problems past the ambient collective public censorship, into people's semi-consciousness, and may, I would suggest, have had profound influence on the subsequent liberalisations, which, however far from complete, were far-reaching.

Pattern as well as moving between $I$ and you also moves between Roman and Italic font, indicating change of voice: not a single stream of consciousness, but a movement between consciousnesses:

25. Following her seminar at the Collège international de philosophie, 1990, and in the context of her work on Les Atrides at the Théâtre du Soleil, Cartoucherie de Vincennes.

26. Cixous also criticized so-called "reality TV" as being fundamentally cruel and gladiatorial, putting women in particular in jeopardy. It could be put forward that various abuses of globalised social media prove her point.

27. Angela Ryan, "Fictions, Factions: Subversive Discourse and Social Politics in Contemporary Women's Writing”, in The Representation of Ireland/s: Images from Outside and from Within, Rosa Gonzáles Casademont (ed.), Barcelona, PPU, 2003, p. 291-299. 
You had sat on the quayside by Notre Dame and looked down at the gleaming water. And he had spoken of the problem of choice, of human dignity, of free decisions. If you love someone half giving is a sin, the only sin, he had said. And you had believed him. Indeed, it had seemed to you a statement so profoundly true that you had wondered why you had never before heard it put into words. Then there had been no turning back.

Those passionate awakenings. Those early summer mornings. The sound of bells calling the hours. The cry of the window-mender passing far below in the quiet street. Vitrier! Vitrier! And the path-sweepers and the dust rising tranquilly along the warm rays of light that pierced the branches, so cool, so still, of the thin-trunked trees in the Luxembourg gardens. [...]

He had said I love you and never again, shall I love another as I now love you, yet I cannot promise you life-long fidelity. I do not believe in such promises. [...]

Failure was now part of the pattern. Once she had dared to be herself and had believed that the rose-garden would be hers forever ${ }^{28}$.

The thematic situation represented in this passage, the question of love-relationships and how they matter to the individuals, and to society as a whole, focalises the psychological jeopardy facing young people, but more especially young women, born around the same time as O'Brien, or as Fitzpatrick Bernard. Marriage is "for life" and there is no divorce. Since relationship breakdowns do happen, nonetheless, outcomes vary. As stated above, there are different possibilities for women in different socio-economic situations. Married women with children, without strong resources (education earning capacity, an independent mind-set, support networks) might be condemned to a lifetime of misery in an unhappy or abusive marriage, with no escape, and surrounded by the expectation that it is "God's will" that she accept her lot. On the other hand, the Irish poet and diplomat Máire Mhac an tSaoi, a dear friend and correspondent of Fitzpatrick Bernard, was able to marry Conor Cruise O'Brien in a Catholic ceremony, on the basis that his earlier marriage to a Presbyterian "did not count" for the Catholic Church and, in that legal structure, had never taken place. Obtaining an annulment from the Vatican, which means declaring formally that the earlier marriage never happened, that its children are extra-marital - something which can be psychologically traumatic -, is used even today. The solution found for the Mhac an tSaoi - Cruise O’Brien wedding was, as Cruise O’Brien himself stated: "hypocritical [...] and otherwise distasteful, but I took it, as preferable to the alternatives" 29 . Until divorce was legalised, others made the same choice.

One of the interesting aspects of my ongoing research on Fitzpatrick Bernard's writing, given the informality of its dissemination, is the question of dates of writing. The metaphoric chain of these passages embraces the romantic images of popular cliché or song, including the reference to a "rose garden", as used in the song "I Never Promised You a Rose Garden", first released in $1967^{30}$, though this

28. Kathleen Fitzpatrick Bernard, "VII Ashes to Ahes", in Pattern, p. 115-118.

29. Conor Cruise O’Brien, Memoir: My Life and Themes, Dublin, Poolbeg, 1999, p. 267. See also Máire Cruise O'Brien, The Same Age as the State, Dublin, O’Brien Press, 2003.

30. Written by Joe South, recorded by Lynn Anderson, first released by Billy Joe Royal in 1967. 
is not the first recorded use of the expression ("rose-tinted glasses", "couleur de rose", "roman à l'eau de rose", etc., being common tropes for romantic love seen at once as desirable, but not perhaps necessarily a realistic aspiration).

Is there a pattern and will there be time. Time to find the answer. And between what waking what sleeping what coming what going what laughter what weeping. What pattern of days of ways of dreams of schemes. Dancing dreams. Blue taffeta schemes. Bright lights over brown Liffey. Grey Seine ${ }^{31}$.

This passage shows typical movement between time and place: discrete ephemeral phenomena ("brown Liffey" then "Grey Seine") are at the same time composed into a situation in time and place where the one is remembered in the context of, though also possibly looking at, the other. The short passage also moves into "total time" with the reflection on whether meaning, "answer" can be found to the question. "Pattern", an aesthetic category, functions as a moral value, a search for an answer. In this passage the growth of awareness referenced by Reynolds and Hourican in relation to O'Brien (see supra) is manifest in Fitzpatrick Bernard's autofiction.

In O'Brien's That Lady, the aristocratic heroine makes a comparable stand for liberty of mind. Ana de Mendoza speaks to "his Most Catholic majesty", Philip of Spain. The King expects to command her love, while leaving her to a lonely widow's life, in the conventions of the time, however nobly-born and rich she is (he later reacts violently to her having a love-relationship with another man, and punishes her by sequestration, in an appalling abuse of power):

I have done no harm to Ruy's memory or my children's name. [...] my private life is truly private. [...] But I do not present my private life to the world. Which is not the same thing as saying that I sacrifice it to the world. I own it, Philip. If I do wrong in it, the wrong is between me and Heaven, But here below, as long as I don't try to change it into public life, I insist that $I$ own it. [...] my private life is all that I own, and I insist on managing it myself, under God ${ }^{32}$.

This is remarkable language to put in the mouth of a heroine of fiction. The $16^{\text {th }}$-century Ana de Mendoza is claiming ownership of her own self, whilst acknowledging the forces around her, but refuting their entitlement. The quest for identity in the writings both of O'Brien and Fitzpatrick Bernard are striking because of the heroine's determined quest for moral autonomy, escape from controlling behaviour, be it physical or psychological.

Fitzpatrick Bernard wrote poetry as well as prose, and in "Isn't she great!" 33 expresses the same moral force of rejection of male entitlement. Here the mood is humorous and the example quotidian, a hostess coping with everyday sexism on the part of guests; the voice speaks nonetheless from behind mental and social

31. Kathleen Fitzpatrick Bernard, "VIII Da Capo", in Pattern, p. 125.

32. Kate O'Brien, That Lady, p. 236.

33. Kathleen Fitzpatrick Bernard, Kitchen Wings, p. 79. 
prison-bars, rather than the walling-up of her living space with which the King punishes Ana's ladylike but absolute rebellion:

Isn't she great!

I hate

all fat-arsed men who sit and wait

while you get into a state

cooking in the kitchen

and then

when you bring in the dishes

slap you on yours and cry

isn't she great!

A young Irish woman travelling to France or Spain, especially at that period, is moving to an elsewhere at once familiar and unfamiliar. Each country has Catholicism as its majority, and also establishment, religion, albeit much more differently configured than might first appear. European history of beliefs displays certain overarching trends, but at the same time, the historical position of religious belief as a matter of politics, and conversely, as social anthropology, has taken particular paths and evolved a variety of counterstructures. Similarities of mindset are also present, for young women educated in convent schools run by religious orders or communities of European origin. Many girls' schools in Ireland were run by French orders, moving to Ireland to develop education, or at the time of the separation of church and state. It is only an apparent paradox that this can have resulted in a more liberal education for young women, than the alternative: The Land of Spices shows an example where the local priest resents his lack of power over the nuns running the school, because the French-origin order has an independent status. Sub-groups of class, political persuasion, religious confession within the Christian belief system, gender, configure themselves and interact in often complex and sometimes surprising ways, including, in some cases, a greater freedom for girls to aspire to intellectual attainment, avoid too early marriage with its corollary of non-chosen frequent pregnancies and other jeopardies cited supra, with the addition of an over-tolerance, until recently, of alcoholism and its disastrous effects on family life. Marriage can also be wonderful, but when it is not, the social conditions weigh heavily on it for women. The risk of death in childbirth in the youth of O'Brien and Fitzpatrick Bernard is not as high as in earlier centuries, but gynaecology is still burdened by imposed restrictions in the name of morality, as well as the progress not yet made in the early $20^{\text {th }}$ century. The I-Persona of Pattern may well fear "ten children".

Agnes, the heroine of O'Brien's The Ante-Room ${ }^{34}$, is comparably horrified at her family's embrace of her syphilitic brother's marriage, albeit with a young woman

34. Kate O'Brien, The Ante-Room [1934], London, Virago, 1989. 
they consider not of their class. The young woman is a nurse, and is assumed to be able to cope with his syphilis and attendant problems, in a time of very limited therapeutics or means of protection for the wife, if expected to accept him as a sexual partner. Otherwise the family would have expected to maintain or improve its social status through marriage, as was the case for Agnes' sister. Here again, everything necessary is said without explicit language, because the outcomes of these problems for women are so concrete and immediate that evocation is enough. The issues are expressed with a combination of revolt, and euphemism, in the modernist stream of consciousness of Agnes' inner voice, waiting in the ante-room of her parents' death. Close observation of small quotidian behaviours says enough.

Agnes must endure scrutiny of her every action. Her sister's marriage is revealed as a failure, because Marie-Rose's husband is in love with Agnes, who loves him in return. As a result the conscientious Agnes has avoided taking communion in church, but her uncle the cleric notices this, and calls her to account. Agnes and her lover agonise over their dilemma, and no solution is found for this serious-minded, ethical, well-suited couple, while religion and propriety accommodate themselves very well to the hypocrisy of concealing the brother's sexually-transmitted illness by a convenient marriage. By this marriage, Agnes, as a woman, will lose status in her family, and her brother's nurse will take a more prominent place. Agnes plans her escape, as does her lover - but not happily.

Both these writers of exile, O'Brien and Fitzpatrick Bernard, focus on themes of travel as escape, elsewhere as the possibility of freedom, in different forms. The speaking subject learns by living and survives by learning. The woman's gaze sees through the masks, hypocrisies and paradoxes by which respectability and socioeconomic dominance are maintained through performance, including of religion.

She cannot however readily truly escape. Elsewhere is not simple, either, and the movement is into different conventions and restrictions, not none. The change offers opportunities, but not for solid future plans. The clarity of observation is internal - what would happen if the heroine spoke out and denounced the pretence around her? If she acknowledged the feelings which threaten the gentrified bourgeois structure, always precarious, however complacent? If the hostess sat down at table to write the poem, instead of serving the smug guest and giving her creativity rein only afterwards? Where, in fact, is the desk of the woman who is a writer? Writing the body is Cixous' metaphoric answer, and a fruitful one. Woolf s "room of one's own" is a problematic solution, for a woman who is married, even more if a mother, because of the list of persons who feel entitled to knock at the door.

The complexity of life, for those who live in an intercultural space, has intercultural aspects. The later lives of both writers appear rather different: O'Brien was married very briefly whereas Kathleen Fitzpatrick and Philippe Bernard were married for many years and had four children, all sharing their parents' intellectual interests and talents in different fields. One spent very little time with Kathleen Fitzpatrick Bernard before realizing how loving was her disposition to her family. This did not mean that there were no difficulties, since it never does. Kate O'Brien's marriage was apparently as brief as it was unhappy; her biographer 
Eibhear Walshe ${ }^{35}$ describes her having had a series of relationships with women, with whom she remained friends as relationships shifted. Mary Lavelle falls passionately in love with a Spaniard, who is passionately in love with her; the ending is not quite unambiguous and one might discern some hope of future union - but not without great difficulty and loss.

Elsewhere is not always an easy place to find happiness, though perhaps easier than at home, for all that, if only for the opportunity to know oneself, offered by travel, as Montaigne articulated centuries earlier. Creative writing, mirroring the passage of time, performs epistemology, learning about learning, in a complex cognitive process of increasingly focused attention on the survival of the self.

Angela Ryan University College Cork

35. Eibhear Walshe, Kate O’Brien: A Writing Life, Newbridge, Irish Academic Press, 2006. 